\title{
Episodic Sedimentation of Heavy Metals and Iron in Bizerte Lagoon, Northern Tunisia
}

\author{
Amor Ben Garali ${ }^{1 *}$, Mohamed Ouakad ${ }^{1}$, Moncef Gueddari ${ }^{2}$ \\ ${ }^{1}$ Faculté des Sciences de Bizerte, Laboratoire de Sédimentologie et Géochimie Marine, Bizerte, Tunisie \\ ${ }^{2}$ Faculté des Sciences de Tunis, Université El Manar, Tunis, Tunisie \\ Email: "bgamor@yahoo.fr
}

Received April 29, 2012; revised September 20, 2012; accepted October 22, 2012

\begin{abstract}
The correlations between various sedimentological and geochemical parameters permit to identify the main sedimentation phases of pollution carriers, especially those related to the sediment cores lithology in Bizerte Lagoon. A close relationship exists between the TOC distribution and the fine fraction $(\mathrm{r}=0.70$; threshold $5 \%)$. This is to identify the formation of organic minerals aggregates. Significant correlations between specific organic matter and heavy metals have been identified. Indeed, the calculated correlation coefficient varies between 0.4 for $\mathrm{Zn}$ and 0.85 for Mn. The enrichment of the intermediate horizons in heavy metals result in specific sedimentations episodes of the pro-deltaic zones. Under these conditions, the surface sediments profit from a "salting-out" phenomenon, which explains the excess of lead observed on the surface. The enriched zones in manganese and zinc correspond to the strongest contents of kaolinite and in smectite, thus, there would be an association with the finest phyllosilicates and/or the colloidal oxyhydroxydes. This is primarily due to the formation of an organic minerals complex via the trapping phenomenon of the argillaceous particles (smectite) and the organic matter of anthropogenic origin. It is to be specified that the presence of metal elements of natural origin $(\mathrm{Mn})$ or anthropogenic origin $(\mathrm{Fe}, \mathrm{Zn}, \mathrm{Pb}$ and $\mathrm{Ni}$ ) which induce the consolidation of these organic minerals complexes.
\end{abstract}

Keywords: Core; Clay Minerals; Organic Matters; Heavy Metals; Bizerte Lagoon; Tunisia

\section{Introduction}

The Bizerte Lagoon is a coastal lagoon of elliptic form $\left(150 \mathrm{~km}^{2}\right.$ surface area) located at northeast Tunisia. It has two major hydrologic connections, the first being freshwater inputs from Garaet Ichkeul via the Tinja Wadi. The second connection is with the Mediterranean Sea via a channel (5 km length; $300 \mathrm{~m}$ width) that empties to the sea via an artificial canal (1500 m length; $140 \mathrm{~m}$ width; $12 \mathrm{~m}$ depth; Figure 1).

The geological depression occupied by the Bizerte Lagoon corresponds to an ante-Neogene solid mass ploughed up and eroded from Messinian timescale (the last age of the Miocene Era) [1,2].

The Triassic series is exhibited in northwest portion of Bizerte, Tunisia, and in the southwest portion of the lagoon system, on the level of Jebel Kchabta [3]. The Pliocene also appears in the southwest portion of Bizerte Lagoon, on the level of Jebel Messeftine [4]. The current coastal morphology of Bizerte Lagoon results from the various sedimentary phases that have occurred since the Miocene Era, and which continue with varying intensity

*Corresponding author. to the present time [5].

Several neighbouring points in the lagoon are causing natural and/or anthropogenic harmful effect in term of heavy metals. Particularly the neighbouring Bizerte industrial zones (cement factory and metals treatment), Menzel Jemil (dyeworks and metallurgy) and Menzel Bourguiba (steelworks El Fouledh, the military arsenal, metallurgy). The same thing is noticed for the detritical material rich in lead of the neighbouring geological grounds of Jbels Kchabta and Messeftine (south of the lagoon) [6].

The sediments play an important role in the hydrochemical cycle which controls the future of metal elements within water systems; they constitute a reservoir of these metal elements and also a pollution tracer $[7,8]$. Indeed, the fine particles, clays and the organic matter are able to trap and concentrate heavy metals by adsorption and complexation mechanisms [9].

[10] indicates that Bizerte lagoon sediments have primarily a muddy to a sandy-muddy nature containing organic matter. The lowest sedimentary TOC contents are observed in the zones pointed out by high percentages of coarse fraction on the Bizerte lagoon, knowing that there 


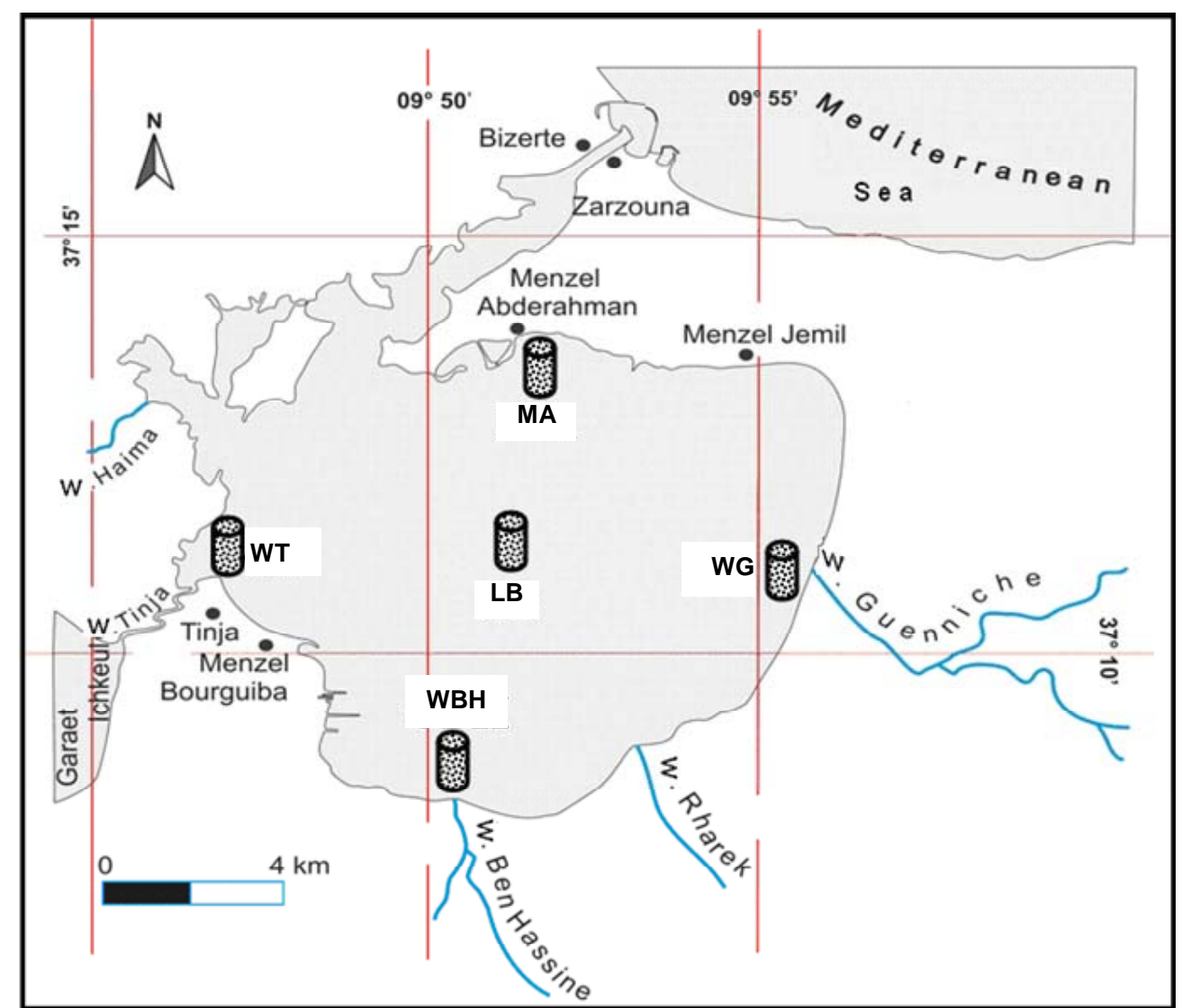

MA: Menzel Abderhman, WT: Wadi Tinja, WBH: Wadi Ben Hassine, WG: Wadi Guenniche, LB: Lagoon of Bizerte.

Figure 1. Location of the extracted cores in the Bizerte Lagoon.

is an incompatibility between coarse sediment and TOC high percentages [11].

[12] shows that heavy minerals present less than $1 \%$ of the sandy sediment of Bizerte bay. [13] supposes that one of the metallic pollution sources is the industrial activities, particularly in the vicinity of Menzel Bourguiba town, the other one, is probably caused by pesticides pollution in the neighboring agricultural zones, and finally by the urban rejections. [14] indicates that the maximum of organic pollution is recorded in the southwestern part of the Bizerte lagoon. The higher contents in organic matter are situated at the central sector sediments which are clayey feature enriched [6].

During diagenesis, the organic matter undergoes a biochemical deterioration which leads up to a loss of the aliphatic chains and globally to a loss of hydro azotes components. However, the major levels show enrichment in carboxylic compounds. The loss in functional groupings can be one of the main causes of some metals desorption phenomenon [6]. This last author indicates that the sedimentary content of $\mathrm{Zn}$ varies between 170 and $260 \mathrm{ppm}$, and show an increase according to the depth.

It is in this context, we studied the behaviour and the vertical distribution of some heavy metals and iron in the sediment of some extracted cores in the Bizerte Lagoon.

\section{Materials and Methods}

Five cores were extracted with PVC tubes by underwater diving on Bizerte Lagoon (Figure 1). The sediments were subjected to grain-size analysis to determine their origin, nature and lithological facies. The percentage of clay minerals is determined by X-ray diffraction method on oriented blades.

This method consists in using the property of X-ray diffraction of a monochromatic beam by the reticular plans, according to BRAGG law.

The grain size analysis allowed us to separate the coarse fraction from fine. This analysis was the object of a succession of treatments to hydrogen peroxide and acetic acid, so the finished product is centrifuged for the deflocculating of the argillaceous fraction.

The oriented aggregates (14 samples) are prepared on glass blades starting from the argillaceous suspension and then passed in diffraction in three states: natural, heated and glycol. The used apparatus is a diffractometer PHILIPS PW 1710, which allows to distinguish the peaks of kaolinite ( 0.02 to $3.57 \AA)$ and of chlorite $(0.04$ to $3.52 \AA)$. The smectite can be specified thanks to their 
properties of swelling when treated by the ethylene glycol; they pass then from (12 - $15 \AA)$ to $17 \AA$. After heating to $500^{\circ} \mathrm{C}$ for 2 hours, kaolinite disappears and only the chlorite persists.

The TOC is determined by the proportion of carbon by using ELTRA CS-2000 apparatus with high temperature combustion in oxygen current $\left(>1200^{\circ} \mathrm{C}\right)$. The total nitrogen is determined by the Kjeldahl method which permits to proportion the sum of organic and ammoniac nitrogen (nitrogenises total).

Considering the richness of the sediment core of the Bizerte Lagoon in coarse fraction, which can reach $100 \%$ and the fraction limit, is of $63 \mu \mathrm{m}$, that's why we carried out the mineralisation of the total sediment.

In this work, we used the dissolution method in open system which is employed because of its simplicity and its low costs. Dissolution in open system is extracted by using a number relatively restricted of strong acids.

We take $100 \mathrm{mg}$ of sediment, and we introduce it in a Teflon spade, the sediment is soaked by bidistilled water. We proceed to the addition at the same time and at three stages of the strong acids according $\left(\mathrm{HNO}_{3}(69 \%), \mathrm{HF}\right.$ $(48 \%)$ and $\left.\mathrm{H}_{2} \mathrm{O}_{2}(30 \%)\right)$ to the total mineralization procedure of sedimentary samples adopted by [15]. Once cooled, the content of the spade is lapsed into a measured flask of $100 \mathrm{~mL}$; the adjustment to the gauge trait is done with bidistilled water. The heavy metals and iron will be measured by the atomic absorption technique (ThermoElemental-Solaar-S4 type).

Several established correlations between the deter-

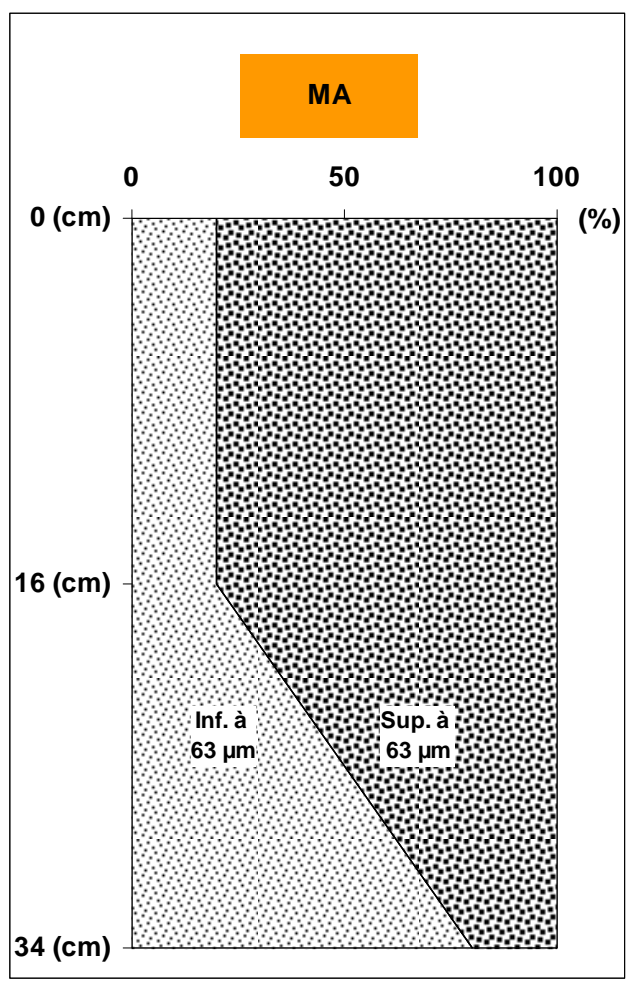

mined parameters, allowed deducting the different possible associations (organic minerals and organometallic).

\section{Results}

An increase in the sedimentary content of fine fraction according to the depth was observed on the cores MA (from $20 \%$ to $80 \%$ ) and WG (from $20 \%$ to $60 \%$ ). The vertical distribution of the fine fraction on the cores of WT and WBH, show an alternation of the contents from the top to the bottom respectively $(75 \% ; 40 \%$ and $65 \%)$ and $(40 \%, 30 \%$ and $70 \%)$. We don't point out any vertical fluctuation of the fine fraction content according to the depth on the LB core (Figure 2).

The semi-quantitative proportions of various clay minerals show that kaolinite is the more dominating clay in the cores sediments of Bizerte lagoon ( $40 \%$ to $65 \%$ ). The illite and the smectite have similar proportions $(10 \%$ to $31 \%$ ) and finally the chlorite (5\% to $17 \%$ ) [16].

These proportions are similar to those recorded during the study of the Spatio-temporal evolution of the clay cortege in the surface sediments of Bizerte lagoon [17].

The vertical evolution of the TOC contents in the sediments of the Bizerte lagoon, shows generally a tendency to increase with the depth along the cores of MA (from $2.2 \%$ to $2.6 \%$ ); WG (from $0.6 \%$ to $1.2 \%$ ) and $\mathrm{WBH}$ (from $1.2 \%$ to $1.7 \%$ ). and WT (from $2.15 \%$ to $2.35 \%$ ). A reduction in the TOC contents with the depth was recorded on the central sector of the lagoon (from $2.26 \%$ to $2.14 \%$ ) [16]. A rythmicity of the sedimentary TOC con-

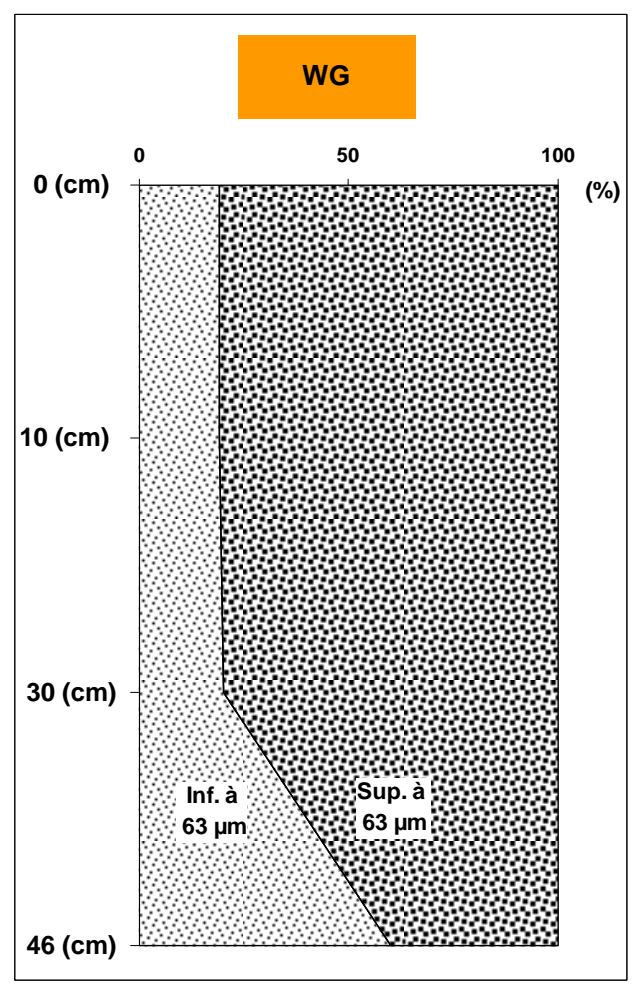




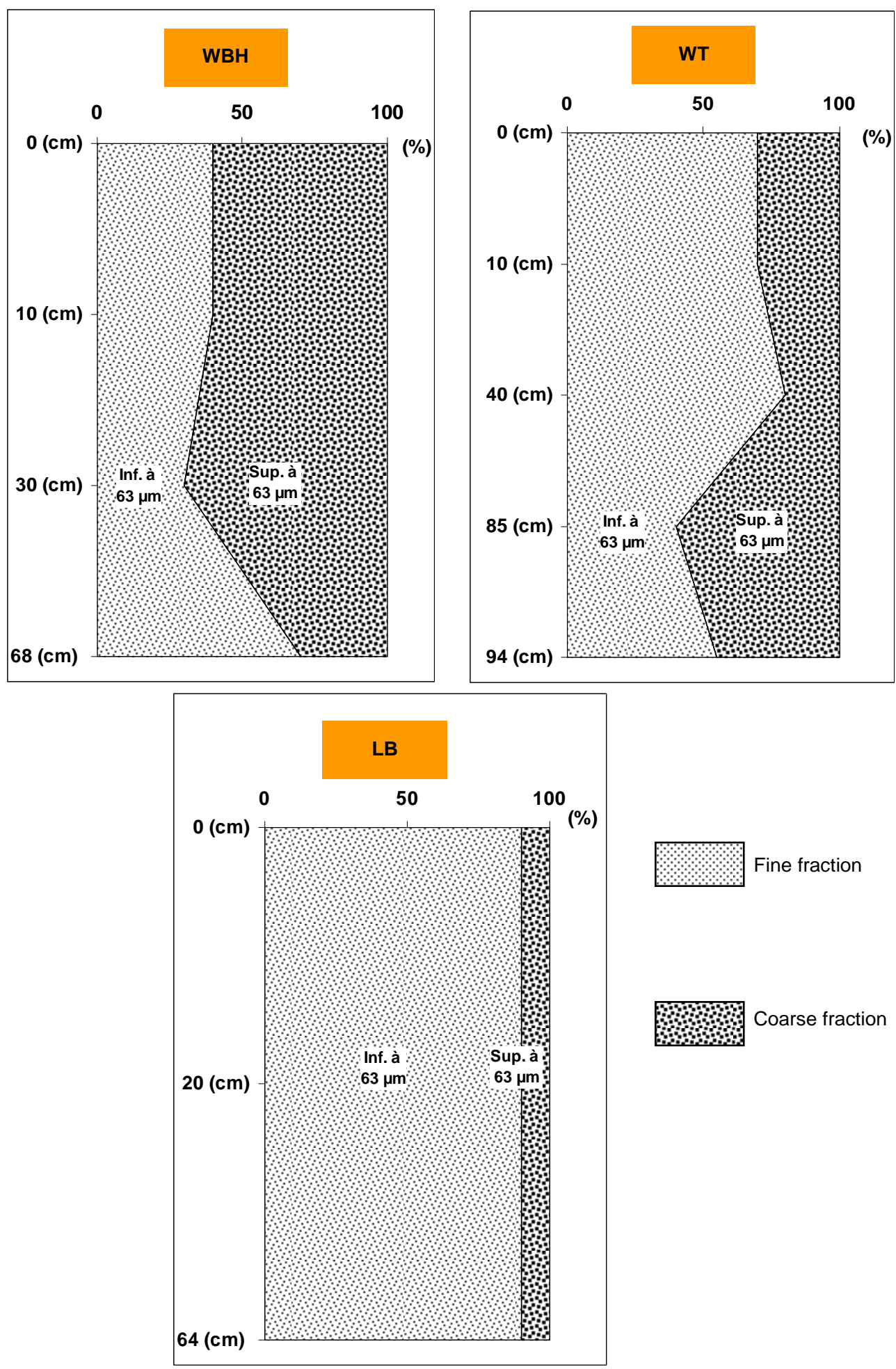

Figure 2. Vertical distribution of the sedimentary contents of fine and coarse fractions in Bizerte Lagoon cores.

tents was recorded along the core of WT namely from the top to the bottom, $2.16 \% ; 2.35 \%$ and $2.16 \%$ [16].

The vertical distribution of total nitrogen shows an increase in the contents on the core sediments of $\mathrm{WBH}$ from $1 \%$ to $1.4 \%$. Then a reduction in the total nitrogen contents is pointed out on the northern sector (MA) and central sector (LB) of the lagoon respectively from $1.7 \%$ to $1.3 \%$ and from $2 \%$ to $0.6 \%$. A vertical alternation of the sedimentary contents total nitrogen was observed from the top to the bottom along cores of WG $(1 \% ; 1.5 \%$ 
and $1 \%)$ of WT $(1.4 \% ; 1.8 \%$ and $1.4 \%)$ [16].

The majority of the core sediments from Bizerte lagoon show an increase in the values of the ratio $\mathrm{C} / \mathrm{N}$ according to the depth, from $1.2 \%$ to $2.5 \%$; from $0.6 \%$ to $1.2 \%$, and $1 \%$ to $3 \%$ respectively for cores of MA, WG and LB. The rythmicity of the values of $\mathrm{C} / \mathrm{N}$ according to the depth was pointed out, namely from the top to the bottom $1.2 \% ; 0.8 \%$ and $1.2 \%$ for core of $\mathrm{WBH}$ and $1.6 \%$; $1.2 \%$ and $1.8 \%$ for core of WT [16].

\subsection{Vertical Distribution of Cobalt (Co)}

On the sediments cores of the stations MA and WT, the Co contents show an increase according to the depth, respectively from 6.14 to $15.98 \mathrm{ppm}$ and 6.84 to 10.4 ppm (Table 1). Contrary, the cobalt contents on the cores WG and WBH show a decrease while going in-depth, respectively of 19.3 to $8.97 \mathrm{ppm}$ and 8.35 to $5.54 \mathrm{ppm}$. In the centre of lagoon (LB), a homogenisation of the cobalt contents was observed along the core (Figure 3 ).

Table 1. Contents of heavy metals and iron sedimentary in Bizerte Lagoon cores.

\begin{tabular}{|c|c|c|c|c|c|c|c|c|c|}
\hline & Co (ppm) & Pb (ppm) & Cd (ppm) & Zn (ppm) & Ni (ppm) & Cu (ppm) & Cr (ppm) & Mn (ppm) & Fe (\%) \\
\hline Detection Limit & 0.1 & 0.1 & 0.01 & 0.1 & 0.1 & 0.1 & 0.1 & 0.1 & - \\
\hline MA: 0 - 16 (cm) & 6.14 & $<0.1$ & $<0.01$ & 170.8 & 29.6 & 10.9 & $<0.1$ & 86.3 & 1.81 \\
\hline MA: 16 - 34 (cm) & 15.98 & $<0.1$ & 0.245 & 158.4 & 27.1 & 4.5 & $<0.1$ & 108.6 & 1.29 \\
\hline WG: 0 - 10 (cm) & 19.3 & 32.1 & $<0.01$ & 149.1 & 44.7 & 19 & 284.5 & 67.5 & 0.49 \\
\hline WG: 10 - 30 (cm) & 10.26 & 93.1 & $<0.01$ & 210.1 & 64.4 & 4.8 & 106.9 & 82.1 & 0.37 \\
\hline WG: 30 - 46 (cm) & 8.97 & 142.7 & $<0.01$ & 185.4 & 66.9 & 11 & 188.9 & 93.3 & 0.29 \\
\hline WBH: 0 - 10 (cm) & 8.35 & 215.8 & $<0.01$ & 182.7 & 72 & 42.6 & $<0.1$ & 56.3 & 1.24 \\
\hline WBH: 10 - 30 (cm) & 7.55 & 287.6 & $<0.01$ & 214.7 & 21.8 & 19.6 & $<0.1$ & 31.2 & 0.86 \\
\hline WBH: 30 - 68 (cm) & 5.54 & 177.7 & $<0.01$ & 233 & 5.4 & 25.6 & 183 & 68.5 & 0.65 \\
\hline WT: 0 - $10(\mathrm{~cm})$ & 6.84 & 197.1 & 0.195 & 32 & 8.8 & 23.4 & 216.1 & 178.7 & 2.22 \\
\hline WT: 40 - 85 (cm) & 2.55 & 191.3 & $<0.01$ & 221.6 & 42 & 15.7 & 53.2 & 122.1 & 1.17 \\
\hline WT: 85 - 94 (cm) & 10.4 & 164.1 & $<0.01$ & 233.1 & 48.5 & 9.8 & 28.7 & 197 & 0.65 \\
\hline LB: 0 - 20 (cm) & 16.8 & $<0.1$ & 0.395 & 229.7 & $<0.1$ & 3 & 163.8 & 98.5 & 0.75 \\
\hline LB: 20 - 64 (cm) & 15.2 & $<0.1$ & 0.28 & 235.7 & 85.8 & 4.3 & 166.6 & 92.8 & 0.55 \\
\hline
\end{tabular}
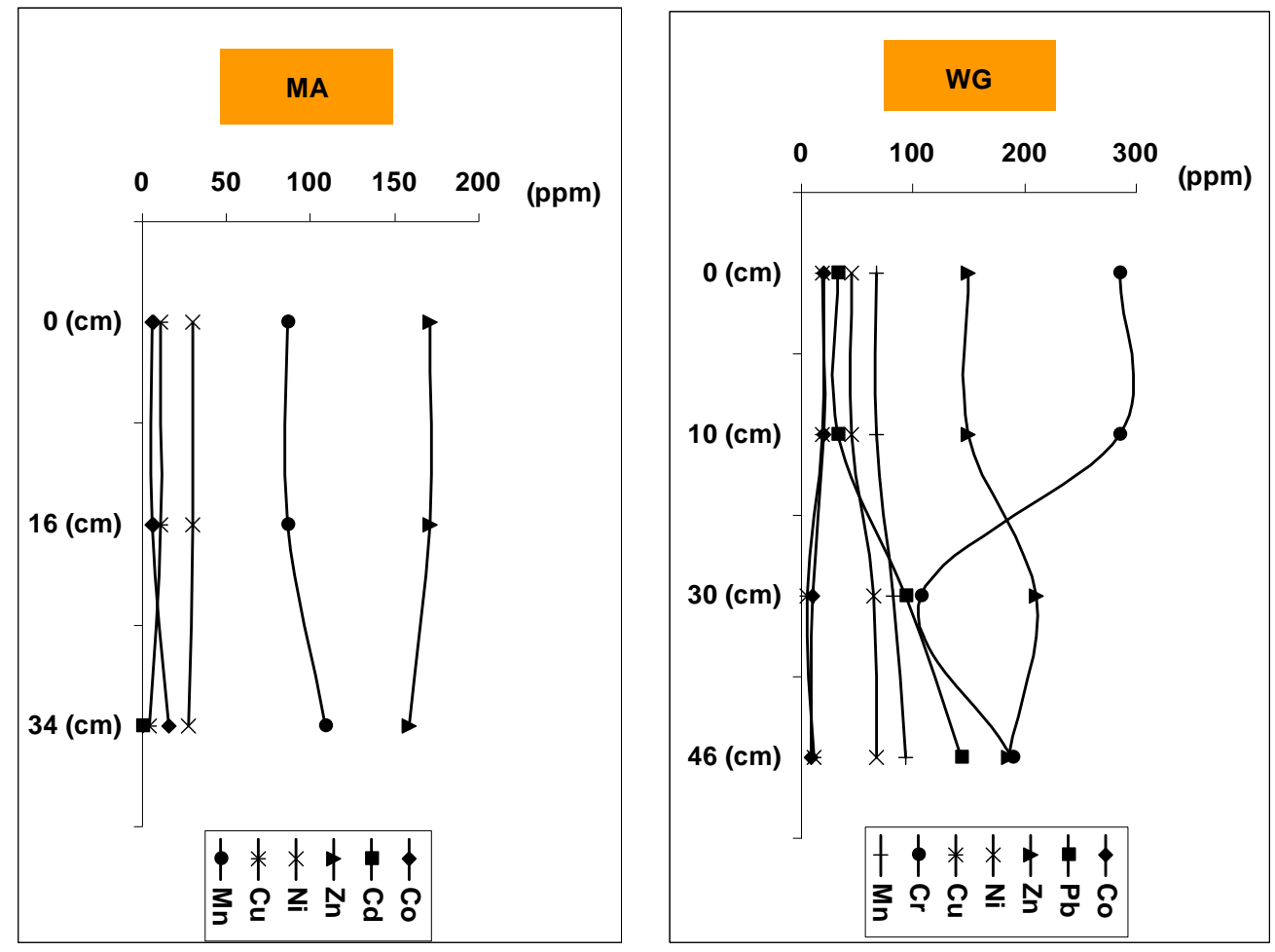

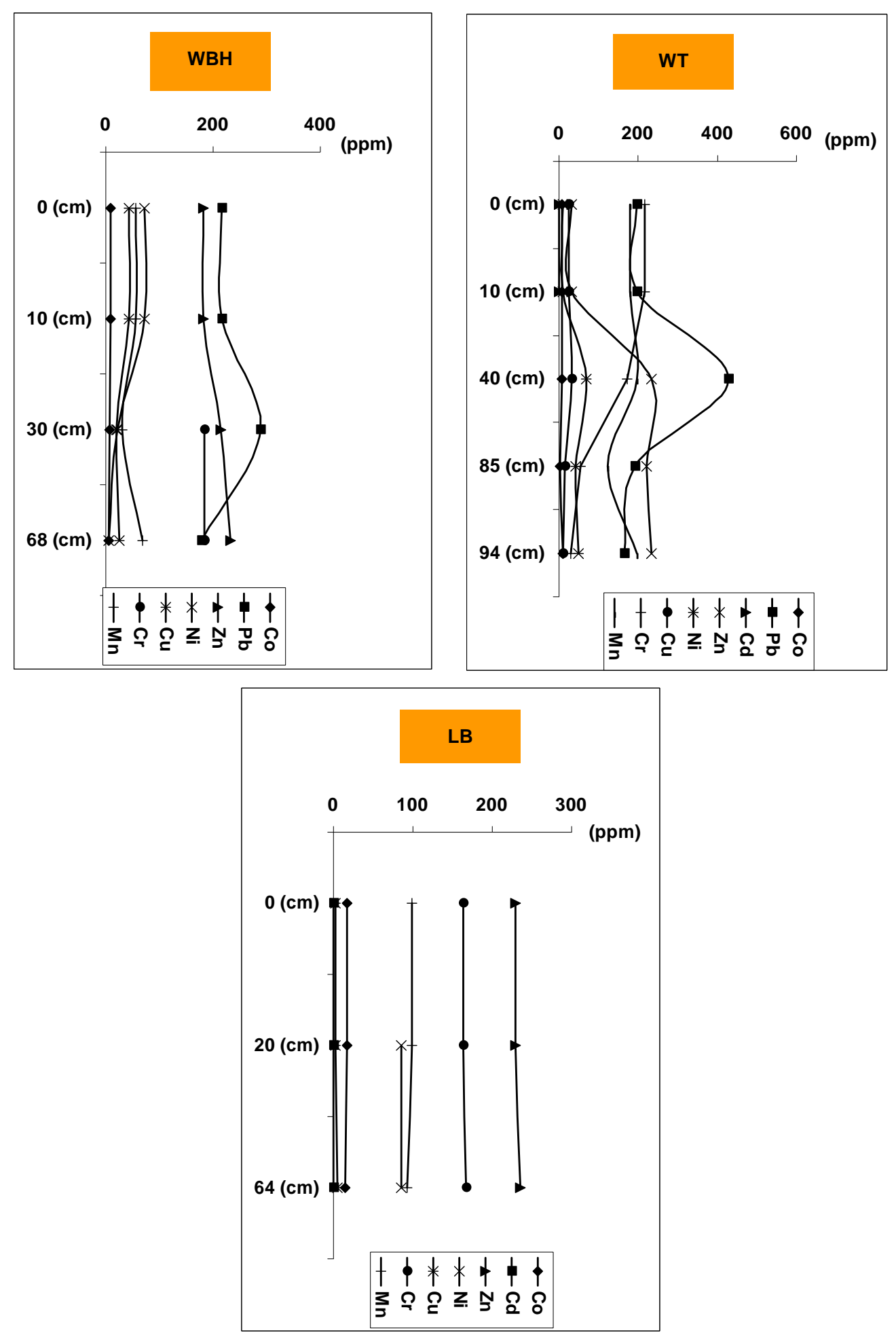

Figure 3. Vertical distribution of heavy metals sedimentary contents in Bizerte Lagoon cores.

\subsection{Vertical Distribution of Lead (Pb)}

The strongest lead content was recorded on the horizon $10-40 \mathrm{~cm}$ of the core WT (428 ppm). In the same way, on the intermediate horizon of core OBH $(10-30 \mathrm{~cm})$, an important accumulation of lead is noticed of approxi- mately $287.6 \mathrm{ppm}$. The sediments of station WG show an increase in the lead contents according to the depth from 32.1 to $142.7 \mathrm{ppm}$ (Table 1). Whereas on the level of cores WBH and WT, the lead content in the sediments, shows a decrease according to the depth, respectively 
from 215.8 to 177.7 and from 197.1 to $164.1 \mathrm{ppm}$ (Figure 3$)$.

\subsection{Vertical Distribution of Cadmium (Cd)}

Cadmium is the less widespread metal in the sediments cores from Bizerte Lagoon; its contents are very weak. The cadmium contents on the sediments cores of WG and of WBH are lower than the limit of detection. The sediments cores of MA don't show any detection of cadmium on the surface horizon whereas a light detection is observed in-depth $(0.245 \mathrm{ppm})$ (Table 1). For cores of WT and LB, a decrease in the cadmium content is observed according to the depth, respectively of 0.195 with $>0.01 \mathrm{ppm}$ and 0.395 to $0.28 \mathrm{ppm}$ (Figure 3 ).

\subsection{Vertical Distribution of Zinc (Zn)}

Zinc is the more represented metal on the sediments cores of Bizerte Lagoon, its contents range between 32 ppm on the horizon of surface of core WT and 235.7 ppm on the bottom horizon of core LB. Sediments core of MA show a decrease in the $\mathrm{Zn}$ contents according to the depth from 170.8 to $158.4 \mathrm{ppm}$ (Table 1). Whereas, an increase in the zinc contents according to the depth is observed on the cores WG, WBH and WT, respectively from 149.1 to 185.4 ; from 182.7 to 233 and 32 to 233.1 ppm (Figure 3). We recorded an important zinc accumulation $(210.1 \mathrm{ppm})$ on the intermediate horizon of the core WG $(10-30 \mathrm{~cm})$.

\subsection{Vertical Distribution of Nickel (Ni)}

The sediments on the cores of MA and WBH show a decrease in the contents of $\mathrm{Ni}$ according to the depth, whereas the rest of the cores show in contrary, an increase in the contents according to the depth (Figure 3). It should be noted that we recorded an important accumulation of nickel of $68.6 \mathrm{ppm}$ on the intermediate horizon of core WT $(10-40 \mathrm{~cm})$ (Table 1). We point out that the Ni content is under the limit of detection on the horizon of surface of core LB.

\subsection{Vertical Distribution of Copper (Cu)}

Copper in the sediments cores of Bizerte Lagoon shows contents which ranges between 1 and $67.4 \mathrm{ppm}$ all horizons confused. The sediments cores on the stations MA, WG, WBH and WT show a decrease in the $\mathrm{Cu}$ contents according to the depth, respectively of 10.9 to 4.5 ; of 19 to 11 ; from 42.6 to 25.6 and 23.4 to 9.8 ppm (Table 1). Whereas it is the reverse is observed on the core of the station LB, with an enrichment of horizon of the bottom from 3 to $4.3 \mathrm{ppm}$ (Figure 3). An accumulation of copper of $31 \mathrm{ppm}$ is recorded on the intermediate horizon of core WT $(10$ - 40).

\subsection{Vertical Distribution of Chromium (Cr)}

The chromium contents ranges between $28.7 \mathrm{ppm}$ on the bottom horizon $(85-94 \mathrm{~cm})$ of core WT and $285.5 \mathrm{ppm}$ on the surface horizon $(0-10 \mathrm{~cm})$ of core WG. We should point out that chromium tends to accumulate on the bottom horizons of core WBH, with $183 \mathrm{ppm}$. It is trapped on the surface of cores of WG $(285.5 \mathrm{ppm})$ and WT (216.1 ppm) (Table 1). There is no vertical fluctuation of chromium on the core LB, with $163.8 \mathrm{ppm}$ on the surface and $166.6 \mathrm{ppm}$ at the bottom (Figure 3). No trace of chromium was recorded on core MA and on surface horizon of core WBH.

\subsection{Vertical Distribution of Manganese (Mn)}

The sediments cores in Bizerte Lagoon are considered to be more or less rich in manganese whose contents range between $31.2 \mathrm{ppm}$ on the horizon $10-30 \mathrm{~cm}$ of core WBH, and $197 \mathrm{ppm}$ at the bottom of core WT. The cores extracted on the stations MA, WG, WBH and WT, show a light increase in the Mn contents according to the depth, respectively from 86.3 to 108.6 ; from 67.5 to 93.3 ; from 56.3 to 68.5 and 178.7 to $197 \mathrm{ppm}$ (Table 1). Whereas such a light decrease according to the depth is observed on core of LB, with 98.5 to $92.8 \mathrm{ppm}$ (Figure 3). We recorded an important manganese accumulation of 196.5 $\mathrm{ppm}$, on the intermediate horizon of core WT (10 - 40 $\mathrm{cm})$.

\subsection{Vertical Distribution of Iron (Fe)}

The highest contents are observed on the surface horizons of all cores extracted from Bizerte Lagoon, with a maximum of $2.25 \%$, observed on the core WT (Table 1). Thus, the vertical evolution shows a decrease in the iron contents while going towards the lower horizons, the minimum $(0.25 \%)$ is recorded on the bottom horizon of core WG (Figure 4).

These results concerning the sedimentary contents of heavy metals and iron along the cores are similar to those recorded in Bizerte lagoon surface sediments [1] (Ben Garali et al., 2010).

\section{Discussion}

The rise in the fine fraction percentage according to the depth on the sediments cores of Bizerte Lagoon could be explained by the existence of a deposit belonging to a distinct sedimentary episode which corresponds to a new sedimentary sequence. The vertical evolution of the sedimentary contents of clay minerals is in close relation, on the one hand, with the volume and the lithological nature of the contributions carted from the catchment area ,and on the other hand, with the mechanisms intervening during the distribution of this fine sedimentary matrix in the 
basin.

Thus, the study of the clay phase on the sediments cores enabled us to show, on the one hand, a light vertical mineralogical heterogeneity, and the existence, on the other hand, of some clay phases characteristics related to the annual and monthly fluctuations of detritical contri-
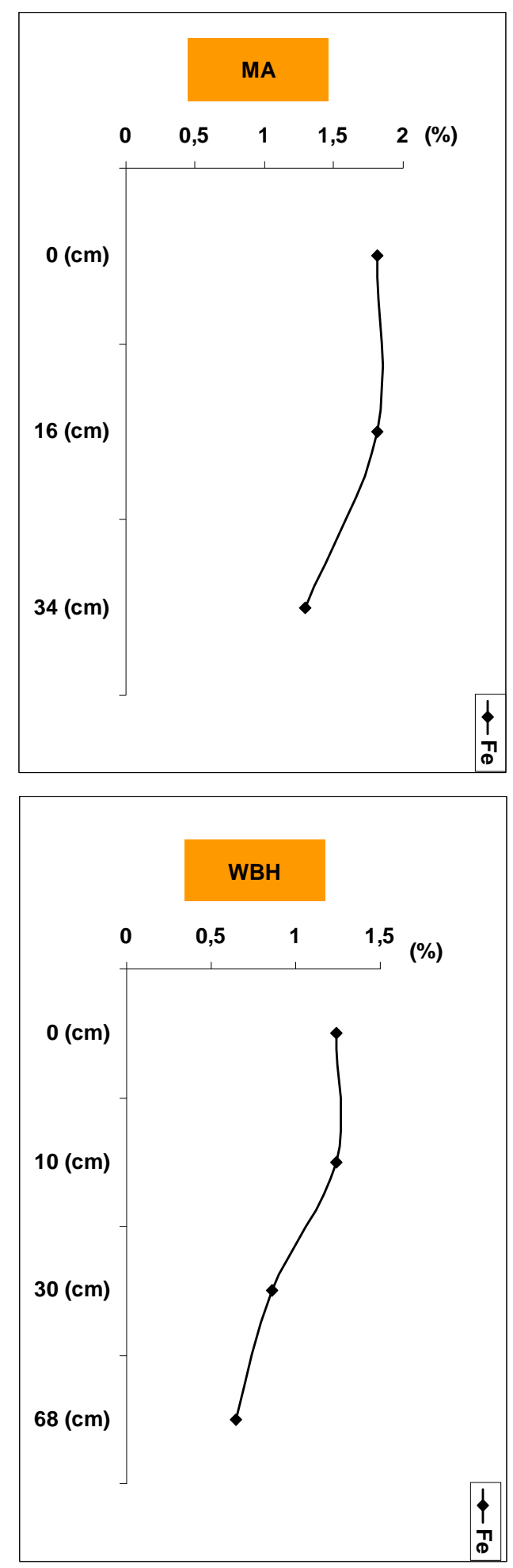

butions by Bizerte lagoon principal affluents [18].

The calculated values of the sedimentation speed at various places of Bizerte Lagoon are just indicative because the obtained results (Table 2) suppose that sedimentation is continuous and not affected by erosion or change phases [10]. Thus, the sedimentation rate remains





Figure 4. Vertical distribution of Iron contents in Bizerte Lagoon cores.

Table 2. Different sedimentation speeds in some zones of the Bizerte Lagoon [10].

\begin{tabular}{|c|c|c|c|c|c|}
\hline Zones & Stations & Nature of the deposit & Bathymetry (m) & $\begin{array}{l}\text { Absolute old } \\
\text { in year B.P }\end{array}$ & $\begin{array}{c}\text { Sedimentation } \\
\text { speed (mm/year) }\end{array}$ \\
\hline West & WT & Mud & 7 & 110 & 2 \\
\hline North to North-West & MA & Alternance of sandy and muddy levels & 4 & 930 & 0.3 \\
\hline Central & LB & Mud & 9 & 300 & 2.5 \\
\hline East to North-East & WG & Sand & 5 & 480 & 0 \\
\hline South & WBH & Alternance of sandy and muddy levels & 4 & - & - \\
\hline
\end{tabular}

more important in the Western and central sectors of the lagoon (2 to $2.5 \mathrm{~mm} / \mathrm{an}$ ), on the northern and eastern sectors ( 0 to $0.3 \mathrm{~mm} /$ year), because of the lithological nature of the deposited sediment and the hydrodynamic parameters within the lagoon. Under these conditions, the space variation of the outcrops lithological nature in the neighbouring lagoon, as well as the spatio-temporal variation of the hydrodynamic parameters in Bizerte Lagoon basin favours a rythmicity of the nature and quantity of the deposited sediment at each place.

The vertical evolution of the organic matter in the sediments of Bizerte Lagoon shows, on majority of the cores, an increase of the TOC contents with the depth.

However, the decrease in TOC contents according to the depth on the central sector of the lagoon, translated the diagenetic effects on the organic matter degradation.

The rhythmic vertical distribution phenomenon of total nitrogen is largely observed on Bizerte Lagoon sediments.
This distribution of the total nitrogen contents confirms our preceding observations relating to the existence of many deposit phases which were already observed during the grain size analysis and the TOC [16].

In the same way, the values of $\mathrm{C} / \mathrm{N}$ ratio show a vertical evolution with a similar rhythm to that observed during the grain size analysis and those of the TOC and total nitrogen. The correlations between various sedimentological and geochemical parameters permit to identify the principal sedimentation phases carrying pollution, in particular those related to the sediment lithology.

During the biological cycle, the organic matter intervenes by biofixation mechanism in the metals concentration and even in the sediments during the diagenetic stages [19]. It can also ensure by biological and/or abiologic oxide-reduction processes the transportation of metals and their deposit in traps. The organometallic complexes mobilization is assuring the metals transportation 
through the lithological layers.

The vertical evolution of the sedimentary contents of fine fraction and argillaceous minerals of Bizerte Lagoon cores induce that the variation of sedimentary contents in lead is not related to the nature of the sediment. It would be rather of chemical nature, in relation with variations primarily of physicochemical nature, translating the desorption phenomenon effect of this element in the sediments. Under these conditions, we would attend to a "salting out" phenomenon to the profit of the surface sediments, which mainly explains the lead excess observed on the surface.

The relatively high manganese rates observed on the surface horizons are related to a "salting out" of this element from interstitial waters, which translates also a good oxygenation of this sector [20]. Indeed, in the presence of oxygen, there is formation of Manganese hydroxide which supports this element sedimentation on the surface layers [21].

The importance of the sedimentary contents in lead, nickel, zinc, copper and manganese on the intermediate horizons of Bizerte Lagoon extracted cores, represents an accumulation of heavy metals during the specific sedimentations episodes characteristic of the pro-deltaic zones. This enrichment of the intermediate horizons induce an abrupt deposit in these elements which are result either of a contribution in excess, or of the temporal variation of the environment physicochemical conditions $(\mathrm{pH}$, salinity, potential of oxydoreduction, temperature, dissolved oxygen, winds...). This highlights the rythmicity in the vertical distribution during the deposit of a new sedimentation episode pointed out during the grain size analysis of the TOC, the total nitrogen and from the values of ratio $\mathrm{C} / \mathrm{N}[16]$.

The complexation phenomenon between metals and organic matter was noticed by [22]. This last author indicates that some clay minerals, manganese and iron oxides play a big role in the flocculation phenomena of some metals as zinc whose contents on the sediments can increase in a very clear way. He adds that the strong gradients of oxide reduction highlighted in the sediment are responsible for phenomena bringing into play the organic matter and metal elements. They result at the same time from fast and episodically accumulation phenomena and from the handing-over in periodic suspensions. This idea supported by [22] confirms the periodic sedimentation of the organic matter, the metal elements and the clay contents.

[23] indicates that the organic matter plays a big role in the sediments enrichment out of iron and manganese. [24] shows the central role of the composed organics in the zinc and copper complexation. For Faguet (1982) [20], the natural sediments and the rich precipitates in iron hydroxides have the strongest adsorbent capacity.
[25] notes the existence of a close relation between organic carbon and some metal elements, primarily zinc, copper and lead. [26] show the existence of an increase in the metal elements contents in the marine sediments. It translated the adsorption and co-precipitation phenomena, without forgetting the biological activity.

These authors state also that the decomposition of the organic matter causes physicochemical properties variations of the basic sediments, which leads to an enrichment of the surface sediment in this matter (interface water-sediment). These organic matter dynamics between surface and basic sediments is favourable to the mobility of metals in the sediments.

Positive correlations are to be noted between heavy metals and fine fraction. Indeed, the correlation coefficient varies between 0.52 and 0.13 , which especially indicates the close relation between the fine fraction and iron at minor degree, manganese, copper, nickel and finally zinc and cadmium. A good correlation exists between the clay phase and the high percentages of manganese $(0.23 ; 0.22$ and 0.21 , respectively for illite, kaolinite and smectite, threshold 5\%) (Table 3).

The zones enriched by manganese and zinc correspond to the strongest kaolinite and smectite contents; there would be thus association with the finest phyllosilicates and/or colloidal oxides hydroxide [27].

In this work, the metal species show a positive correlation, respectively, with the fine fraction and total nitrogen, $\mathrm{Pb}(0.23$ and 0.20$), \mathrm{Cd}(0.13$ and 0.48$), \mathrm{Ni}(0.19$ and $0.20), \mathrm{Cu}(0.20$ and 0.22$)$ and $\mathrm{Fe}(0.52$ and 0.62$)$ (threshold 5\%). Zn (0.13 and 0.11) and Mn (0.25 and 0.48) (threshold 5\%) are correlated positively, respectively with the fine fraction and TOC (Table 3).

In the same way, positive correlations are to be noted between the different metal species. The most important correlation is between Mn and Iron $(r=0.50$; threshold $5 \%$ ). Such an important correlation exists between the $\mathrm{Pb}$, and the $\mathrm{Cu}$ and $\mathrm{Cr}(\mathrm{r}=0.42$; threshold $5 \%)$. Then between $\mathrm{Cr}$ and $\mathrm{Mn}, \mathrm{Ni}$ and Iron, $\mathrm{Cr}$ and $\mathrm{Cd}, \mathrm{Fe}$ and $\mathrm{Zn}$, with coefficients respectively of $0.29 ; 0.27 ; 0.24$ and 0.19 (threshold 5\%). Finally between, Co, on the one hand, and $\mathrm{Zn}$ and $\mathrm{Cd}$, on the other hand, respectively of 0.17 and 0.15 (threshold 5\%) (Table 3).

These results show the big role played by iron and chromium in the fixing of other metals. Thus, each one of these two metals shows four types of possible metal combinations with other metals:

${ }^{*} \mathrm{Fe}-\mathrm{Mn}(\mathrm{r}=0.50$; threshold $5 \%)$, Fe-Ni $(\mathrm{r}=0.27$; threshold 5\%),

Fe-Zn $(r=0.19$; threshold 5\%), and Fe-Co $(r=0.10$; threshold 5\%).

${ }^{*} \mathrm{Cr}-\mathrm{Pb}(\mathrm{r}=0.42 ;$ threshold $5 \%), \mathrm{Cr}-\mathrm{Mn}(\mathrm{r}=0.29 ;$ threshold 5\%),

$\mathrm{Cr}-\mathrm{Cd}(\mathrm{r}=0.24$; threshold $5 \%)$, and $\mathrm{Cr}-\mathrm{Cu}(\mathrm{r}=0.13$; 
Table 3. Correlations between different analysed parameters from the sediments cores of Bizerte Lagoon (Ben Garali et al., 2010).

\begin{tabular}{|c|c|c|c|c|c|c|c|c|c|c|c|c|c|c|}
\hline & $\mathbf{F F}$ & $\mathbf{K}$ & $S$ & I & C & TOC & Nt & $\mathbf{P b}$ & Cd & Zn & $\mathbf{N i}$ & $\mathbf{C u}$ & Mn & $\mathbf{F e}$ \\
\hline FF & 1 & & & & & & & & & & & & & \\
\hline $\mathbf{K}$ & 0.95 & 1 & & & & & & & & & & & & \\
\hline S & 0.96 & 0.98 & 1 & & & & & & & & & & & \\
\hline I & 0.96 & 0.99 & 0.99 & 1 & & & & & & & & & & \\
\hline C & 0.91 & 0.97 & 0.95 & 0.96 & 1.00 & & & & & & & & & \\
\hline TOC & 0.71 & 0.65 & 0.60 & 0.63 & 0.60 & 1 & & & & & & & & \\
\hline Nt & 0.03 & -0.10 & -0.07 & -0.09 & -0.01 & -0.09 & 1 & & & & & & & \\
\hline $\mathbf{P b}$ & 0.24 & -0.02 & 0.00 & 0.01 & -0.06 & -0.27 & 0.20 & 1 & & & & & & \\
\hline Cd & 0.14 & -0.07 & 0.03 & -0.01 & -0.01 & -0.04 & 0.49 & -0.16 & 1 & & & & & \\
\hline Zn & 0.14 & 0.08 & 0.10 & 0.09 & -0.02 & 0.11 & -0.30 & -0.27 & -0.11 & 1 & & & & \\
\hline $\mathbf{N i}$ & 0.20 & 0.36 & 0.29 & 0.31 & 0.33 & 0.21 & 0.20 & -0.08 & -0.52 & 0.09 & 1 & & & \\
\hline $\mathrm{Cu}$ & 0.20 & 0.18 & 0.21 & 0.23 & 0.18 & -0.19 & 0.22 & 0.42 & 0.01 & -0.18 & 0.07 & 1 & & \\
\hline Mn & 0.25 & 0.22 & 0.21 & 0.23 & 0.20 & 0.49 & 0.20 & 0.04 & 0.10 & -0.39 & -0.12 & 0.10 & 1 & \\
\hline $\mathbf{F e}$ & 0.53 & 0.53 & 0.56 & 0.55 & 0.44 & 0.63 & 0.63 & -0.19 & -0.26 & 0.19 & 0.27 & 0.09 & 0.50 & 1 \\
\hline
\end{tabular}

FF: Fine Fraction, K: Kaolinite, S: Smectite, I: Illite, C: Chlorite, TOC: Total Organic Carbon, Nt: total Nitrogen, Pb: Lead, Cd: Cadmium, Zn: Zinc, Cu: Copper, Ni: Nickel, Mn: Manganese, Fe: Iron.

threshold 5\%).

A close relation exists between the TOC distribution and the fine fraction $(\mathrm{r}=0.70$; threshold $5 \%)$. Also, we notice a preferential association between smectite and TOC $(r=0.60$; threshold 5\%) (Table 3).

These results helped to better understand the various interactions that can occur in Bizerte Lagoon sediments between heavy metals, clay minerals and organic matter. We also specified that the presence of metal elements of natural origin $(\mathrm{Mn})$ or anthropogenic $(\mathrm{Fe}, \mathrm{Zn}, \mathrm{Pb}$ and $\mathrm{Ni}$ ) induce the consolidation of these organic minerals and/or metallic complexes.

\section{Conclusion}

The formation and the stability of the sedimentary aggregates, resulting from the complexation of the fine particles with the organic matter in presence of metal elements depend of several factors. In order to study the behaviour and the vertical distribution of some heavy metals and iron in the sediments of the Bizerte Lagoon, some cores were extracted. This highlighted the rhythmicity in the vertical distribution during the deposit of a new sedimentation episode of the fine fraction, argillaceous minerals, TOC, total nitrogen, heavy metals and iron. These results show also the important role played by iron and chromium in the fixing of other metals. In prospect, all of these results allow us in an eventual future work, with an accurate calculation of the sedimentation rate, to rebuild the various stages and process of such specific lagoon sedimentation.

\section{REFERENCES}

[1] P. F. Burollet, "Etude Géologique des Bassins MioPliocenes du Nord-Est de la Tunisie," Annales des Mines et de la Géologie, Vol. 7, 1951, pp. 5-86.

[2] M. Andrieu, "Prospections Electriques au sud du lac de Bizerte," Rapport Interantional, Tunis, 1971.

[3] N. Crampon, "Etude Géologique de la Bordure des Mogods du 'Pays de Bizerte' et du Nord de Hedil (Tunisie Septentrionale)," Docteur ès Sciences, Nancy I, 1971.

[4] M. Ouakad, "Etude Sédimentologique et Caractères Géochimiques des Dépôts Récents de la Garaet el Ichkeul (Tunisie Septentrionale)," Thèse de 3ème Cycle, Université de Perpignan, Perpignan, 1982, p.166.

[5] S. Mathlouthi, "Etude Géomorphologique des Environs du Système Lacustre de Bizerte," Thèse de Doctorat de Spécialité, Université de Tunis I, Tunis, 1985, p. 287.

[6] M. Ouakad, "Genèse et Evolution des Milieux LagunoLacustres du Nord-est de la Tunisie (Garaet Ichkeul, Lagunes de Bizerte er Ghar el Melh)," Thèse Doct. Es, Université de Tunis El Manar, Tunis, 2007, p. 453.

[7] U. Forstner and G. T. W. Wittman, "Metal Pollution in the Aquatic Environnement," Springer-Verlag, Berlin, 1981, p. 486. doi:10.1007/978-3-642-69385-4

[8] W. Salomons, "Trace Metal Analysis on Polluted Sediments Part II, Evaluation of Environnemental Impact," Science technology, Letters, Vol. 1, No. 11, 1980, pp. 506-517.

[9] C. K. Jain, "Metal Fractionation Study on Bed Sediments 
of Rivers Yamuna, India," Water Research, Vol. 38, No. 3, 2004, pp. 569-578. doi:10.1016/j.watres.2003.10.042

[10] N. Soussi, "Mécanismes de la Sédimentation et Evolution Paléogéographique de la Lagune de Bizerte (Tunisie) Durant le Quaternaire Récent," Thèse 3 Cycle, University of Paul Sabatier, Toulouse, 1981.

[11] F. Gadel, "La Matière Organique et la Sédimentation Récente Dans le Golfe du Lion. Distribution, Nature et Evolution," Thèse D'état, University of Paris, Paris, 1975.

[12] J. Watkins and O. H. Pilkey, "Le Sable des Plages Tunisienne," Notes Services Géologiques, Office National des Mines, Tunis, 1973, pp. 337-392.

[13] M. Yoshida, "Mobility of Potentially Toxic Element from the Bottom Sediment of Bizerte Lagoon-Sequential Leaches and Acid Extraction," Final Report Research Promotion Programme, 2004, pp. 55-70.

[14] F. Srarfi, "Etude Géochimique et état de Pollution de la Lagune de Bizerte," Thèse 3 Cycle de Géologie, University of Tunis el Manar, Tunis, 2007.

[15] B. R. Martin, "Répartition et Fractionnement Géochimique des Eléments Traces Dans les Sédiments Marins. Applications à la Marge Continentale du Golfe de Lion," Ph.D. Thesis, University of Perpignan, Perpignan, 1998.

[16] A. Ben Garali, M. Ouakad and M. Gueddari, "Geochemistry of Episodic Sedimentation in Bizerte Lagoon (Northern Tunisia)," Lakes and Reservoirs: Research and Management, Vol. 15, No. 3, 2010, pp. 273-282. doi:10.1111/j.1440-1770.2010.00433.x

[17] A. Ben Garali, M. Ouakad and M. Gueddari, "Evolution Spatio-Temporelle du Cortège Argileux Dans es Sédiments Superficiels de la Lagune de Bizerte (Tunisie Septentrionale)," Africa Geoscience Review, Vol. 15, No. 3, 2008, pp. 279-286.

[18] A. Ben Garali, M. Ouakad and M. Gueddari, "Bilans Hydrologiques de la Lagune de Bizerte (Nord-Est de la Tunisie)," Revue des Sciences de l'Eau, Vol. 22, No. 4, 2009, pp. 523-534.

[19] J. Trichet, “Etude des Premiers Stades D'évolution de la Matière Organique Dans des Vases en Milieu Récifal
(Polynésie)," In: G. D. Hobson and G. C. Speers, Eds., Advances in Organic Geochemistry, Pergamon Press, Oxford, 1996, pp. 265-284.

[20] D. Faguet, "Influence des Substrats Humiques sur les Formes Dissoutes et Particulaires de Quelques Métaux ( $\mathrm{Zn}, \mathrm{Fe}, \mathrm{Co}$, et Mn) Dans les Milieux Marins et Lagunaires," Thèse de Spéc, University of Perpignan, Perpignan, 1982.

[21] M. Huettel, W. Ziebis, S. Forster and G. W. Luther, "Adective Transport Affecting Metal and Nutient Distributions and Interfacial Fluxes in Permeable Sediments," Geochimica et Cosmochimica Acta, Vol. 62, No. 4, 1998, pp. 613-631. doi:10.1016/S0016-7037(97)00371-2

[22] G. Cauwet, "Dynamique de la Matière Organique Dans les Milieux Marins et Polyhalins, Son Rôle Dans les Processus Géochimiques aux Interfaces," Ph.D. Thesis, University of Perpignan, Perpignan, 1985.

[23] C. E. Lambert, "Le Cycle Interne du fer et du Manganèse et Leurs Interactions Avec la Matière Organique Dans L'océan," Thèse de spécialité, University of Nice, Nice, 1981.

[24] H. Bertrand, "Les Insectes Aquatiques d'Europe," Le Chevalier, Paris, 1979.

[25] J. M. Jouanneau, "Matières en Suspension et Oligoéléments Métalliques Dans le Système Estuarien Girondin: Comportement et Flux," Ph.D. Thesis, University of Bordeaux I, Bordeaux, 1989.

[26] J. C. Fauger, M. Martineau, D. Bonjour, J. B. Saliners and B. Caurial, "Application de la Mesure du Carbone Organique Dissous et Particulaire au cas du Bassin d'Arcachon, Gironde, France," Cours Intensif Européen. Connaissance et Gestion de la Frange Littorale et du Proche Plateau Continentale, Strasbourg, 1989.

[27] A. Ben Garali, M. Ouakad and M. Gueddari, "Contamination of Superficial Sediments by Heavy Metals and Iron in the Bizerte Lagoon, Northern Tunisia," Arabian Journal of Geosciences, Vol. 3, No. 3, 2010, pp. 295-306. doi:10.1007/s12517-009-0082-9 